\title{
軟組織を最大限に付着するオトガイ骨切り前方 移動形成術の術後安定性について
}

\author{
猪田博文・山口芳功*.大槻哲也*.吉武一貞* \\ Postoperative stability of broad soft tissue pedicle genioplasty.
}

\author{
Hirofumi INODA $\cdot$ Yoshinori YAMAGUCHI ${ }^{*}$ \\ Tetsuya OHтsuki ${ }^{*} \cdot$ Kazusada Yoshitake*
}

\begin{abstract}
We evaluated the postoperative stability of broad soft tissue pedicle genioplasty. This surgical procedure involves horizontal osteotomy of the inferior border of the mandible while maintaining a musculoperiosteal pedicle.

Lateral chephalometric radiographs of 20 patients who underwent broad soft tissue pedicle genioplasty were analyzed to evaluate osseous and soft tissue changes of the chin. We found that the pedicled genial segment had no relapse, and the soft tissue had only slight relapse. In addition, bone remodeling was seen at the symphysis of the genial segment. Broad soft tissue pedicle genioplasty had good postoperative stability.
\end{abstract}

Key words: 術後安定性 (postoperative stability)，オトガイ形成術 (genioplasty)，セファロ分析 (cephalometric analysis)

\section{緒言}

オトガイ形成術は顎変形症の手術の際, 良好なプロ フィール獲得のための重要な手術の一つとされている. 近年, オトガイ部の骨を切断し，軟組織を最大限に付

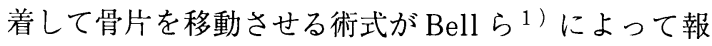
告されている。この軟組織を最大限に付着するオトガ 亿前方移動形成術の術後安定性について検討の報告は 本邦においては少なく2,3)，また，多数症例について の検討は見あたらない. 本研究の目的は顎変形症の手 術の際, 本術式と Intraoral Vertical Ramus Osteotomy（以下 I. V. R. O) を行った14例，本術式と Le Fort I 型骨切り術と I. V. R. O を組み合わせた 6 例 の合計20例について, オトガイ部の硬組織, 軟組織の 術後安定性を検討することにある。

\section{公立湖北総合病院㐘科口腔外科}

(主任 : 猪田博文医長)

*滋賀医科大学歯科口腔外科学講座

（主任 : 吉武一貞教授）

Department of Oral and Maxillofacial Surgery, Kohoku General Hospital (Chief: Hirofumi Inoda)

*Department of Oral and Maxillofacial Surgery, Shiga University of Medical Science (Chief: Prof. Kazusada Yoshitake)

受付日: 平成 8 年11月21日

\section{対象と方法}

\section{1. 対象症例}

対象症例は1989年 2 月から1994年 7 月までに滋賀医 科大学歯科口腔外科で, 下顎前突症と診断され, 外科 的矯正治療の際, I. V. R. O と軟組織付着を最大限に 保存するオトガイ骨切り前方移動形成術を実施した 14 例と, Le Fort I 型骨切り術, I. V. R. O, 軟組織を最 大限に付着するオトガイ骨切り前方移動形成術を施行 した 6 例, 合計 20 例である. 内容は男性 5 人, 女性 15 人, 手術時年齢は17歳から 28 歳, 平均年澮は22.2歳であっ た（表 1 ）。また, オトガイ部骨片はミニプレートにて 固定し, 顎間固定期間は 2 週間とした。観察期間は術 前, 術後 1 か月, 術後 6 か月, 術後12か月とした。

\section{2. 分析方法}

それぞれの症例の側方頭部 X 線規格写真 (以下七 ファロ）を用いて計測点を以下のように設定した。

1 ) 硬組織オトガイ点

セファロの FH 平面上に垂直投影される硬組織オト ガイ部の最前出点を, 硬組織オトガイ点 (以下 Pog) とした.

2 ) 軟組織オトガイ点

セファロの FH 平面上に垂直投影される軟組織オト ガイ部の最前出点を, 軟組織オトガイ点（以下 Pogs） とした。

今回の対象症例はすべてオトガイ部を前方に移動さ 
$\sim$ 表 1 症例

\begin{tabular}{rrll}
\hline 症例 & $\begin{array}{c}\text { 年歯 } \\
\text { (歳) }\end{array}$ & 性別 & 手術術式 \\
\hline 1 & 22 & 女 & 1,2 \\
2 & 24 & 女 & 1,2 \\
3 & 20 & 女 & $1,2,3$ \\
4 & 21 & 女 & 1,2 \\
5 & 26 & 女 & $1,2,3$ \\
6 & 20 & 女 & $1,2,3$ \\
7 & 19 & 女 & 1,2 \\
8 & 20 & 男 & 1,2 \\
9 & 20 & 男 & 1,2 \\
10 & 19 & 女 & $1,2,3$ \\
11 & 23 & 女 & 1,2 \\
12 & 25 & 女 & $1,2,3$ \\
13 & 21 & 男 & 1,2 \\
14 & 20 & 女 & 1,2 \\
15 & 22 & 男 & 1,2 \\
16 & 23 & 女 & 1,2 \\
17 & 25 & 女 & $1,2,3$ \\
18 & 28 & 女 & 1,2 \\
19 & 28 & 男 & 1,2 \\
20 & 17 & 女 & 1,2 \\
\hline & &
\end{tabular}

手術術式

$1:$ 軟組織を最大限に付着す るオトガイ骨切り前方移 動形成術

2 : I. V. R. O

3 : Le Fort I 型骨切り術
表 2 硬組織オトガイ点 (Pog) の水平的位置変化量

\begin{tabular}{cccc}
\hline 症例 & 手術時の移動量 $(\mathrm{mm})$ & $\Delta \operatorname{Pog} 1(\mathrm{~mm})$ & $\Delta \mathrm{Pog} 2(\mathrm{~mm})$ \\
\hline 1 & 1.0 & 0 & 0 \\
2 & 3.0 & 0 & 0 \\
3 & 3.0 & -0.5 & 0 \\
4 & 5.0 & 0 & 0 \\
5 & 6.5 & 0 & 0 \\
6 & 6.5 & 0 & 0 \\
7 & 6.0 & 0 & 0 \\
8 & 7.0 & -0.5 & 0 \\
9 & 5.0 & 0 & 0 \\
10 & 7.0 & 0 & 0 \\
11 & 5.0 & 0 & 0 \\
12 & 5.0 & 0 & 0 \\
13 & 7.5 & 0 & 0 \\
14 & 5.5 & 0 & 0 \\
15 & 3.0 & 0 & 0 \\
16 & 4.0 & 0 & 0 \\
17 & 3.5 & 0 & 0 \\
18 & 6.0 & 0 & 0 \\
19 & 4.5 & 0 & 0 \\
20 & 2.0 & 0 & 0 \\
\hline 平均 & 4.8 & -0.1 & 0 \\
\hline
\end{tabular}

手術時の移動量 : 術前と術後 1 か月のセファロの Pog を FH 平面に垂直投影した時の水平的移動量

$\operatorname{Pog} 1$ : 術後 1 か月と術後 6 か月のセファロの $\mathrm{Pog}$ を $\mathrm{FH}$ 平面に垂直投影した時の水平的移動量 Pog 2 : 術後 6 か月と術後 12 か月のセファロの $\mathrm{Pog}$ を $\mathrm{FH}$ 平面に垂直投影した時の水平的移動量
表 3 軟組織オトガイ点 (Pogs) の水平的位置変化量

\begin{tabular}{cccc}
\hline 症例 & 手術時の移動量 $(\mathrm{mm}) \Delta \mathrm{Pogs} 1(\mathrm{~mm}) \Delta \mathrm{Pogs} 2(\mathrm{~mm})$ \\
\hline 1 & 3.0 & 0 & 0 \\
2 & 2.5 & -1.0 & 0 \\
3 & 2.0 & -1.0 & 0 \\
4 & 5.0 & -0.5 & 0 \\
5 & 4.5 & -1.5 & -0.5 \\
6 & 6.5 & -1.0 & 0 \\
7 & 3.0 & 0 & 0 \\
8 & 6.0 & -0.5 & -0.5 \\
9 & 2.5 & 0 & 0 \\
10 & 4.0 & 0 & -0.5 \\
11 & 4.5 & 0 & -0.5 \\
12 & 4.5 & 0 & -0.5 \\
13 & 3.5 & -0.5 & 0 \\
14 & 5.0 & 0 & 0 \\
15 & 2.0 & -0.5 & 0 \\
16 & 2.0 & 0 & 0 \\
17 & 2.5 & 0 & 0 \\
18 & 5.0 & -0.5 & -0.5 \\
19 & 1.0 & 0 & 0 \\
20 & 1.5 & 0 & 0 \\
\hline 平均 & 3.5 & -0.4 & -0.2 \\
\hline
\end{tabular}

手術時の移動量 : 術前と術後 1 か月のセファロの Pogs を $\mathrm{FH}$ 平面に垂直投影した時の水平的移動量

Pogs 1 : 術後 1 か月と術後 6 か月のセファロの pogs $\mathrm{FH}$ 平面に垂直投影した時の水平的移動量 Pogs 2 : 術後 6 か月と術後 12 か月のセファロの pogs $\mathrm{FH}$ 平面に垂直投影した時の水平的移動量
せた症例であり，検討は術前のセファロの下顎骨部を 下顎前歯部舌側皮質骨，下顎骨下縁，下顎管を基準に してセファロに重稀わせ, 硬組織オトガイ点と軟組 織オトガイ点を術後 1 か月のセファロ上の $\mathrm{FH}$ 平面に 垂直投影し, 手術時の移動量を測定した。また術後 6 か月, 術後 12 か月の下顎骨部を同様の基準で術後 1 か 月のセファロと重ね合わせ, 硬組織オトガイ点, 軟組 織オトガイ点を $\mathrm{FH}$ 平面に垂直投影し, 水平的位置変 化の前方移動をプラス表示, 後方移動をマイナス表示 にて測定し, 検討した（図1）.

\section{3 . 分析項目}

\section{1 ) 硬組織オトガイ点 (Pog) について}

術前, 術後 1 か月, 術後 6 か月, 術後12か月について 術後 1 か月のセファロ上の $\mathrm{FH}$ 平面に投影し, 手術時 の移動量と術後 1 か月から術後 6 只, 術後 6 か月か ら術後12か月のそれぞれの水平的位置変化量を $\triangle \mathrm{Pog} 1$, $\triangle \operatorname{Pog} 2$ として計測した.

\section{2 ) 軟組織オトガイ点 (Pogs) について}

術前, 術後 1 力月, 術後 6 か月, 術後12か月について 術後 1 か月のセファロ上の $\mathrm{FH}$ 平面に投影し, 手術時
の移動量と術後 1 か月から術後 6 力月, 術後 6 か月から 術後12か月のそれぞれの水平的位置変化量を $\triangle \mathrm{Pogs} 1$, $\triangle$ Pogs 2 として計測した.

3 ) 術後12か月までの移動骨片の骨の添加, 吸収の 形態について検討を行った.

\section{結果}

\section{1. 硬組織オトガイ点の水平的位置変化について}

硬組織オトガイ点の平均移動量は $4.8 \mathrm{~mm}$ であり, 術 後 1 か月から術後 6 か月の平均水平的位置変化量は $-0.1 \mathrm{~mm}$. 術後 6 か月から術後 12 力月の平均水平的位 置変化量は $0.0 \mathrm{~mm}$ であった (表 2 ).

\section{2. 軟組織オトガイ点の水平的位置変化について}

軟組織オトガイ点の平均移動量は $3.5 \mathrm{~mm}$ であり, 術 後 1 か月から術後 6 か月の平均水平的位置変化量は $-0.4 \mathrm{~mm}$. 術後 6 か月加術後 12 加の平均水平的位 置変化量はー0.2mmであった（表 3 ).

\section{3 . 術後 12 か月までの移動骨片の吸収, 添加の形態 について \\ すべての怔例について, 移動骨片の前上方部に骨吸}




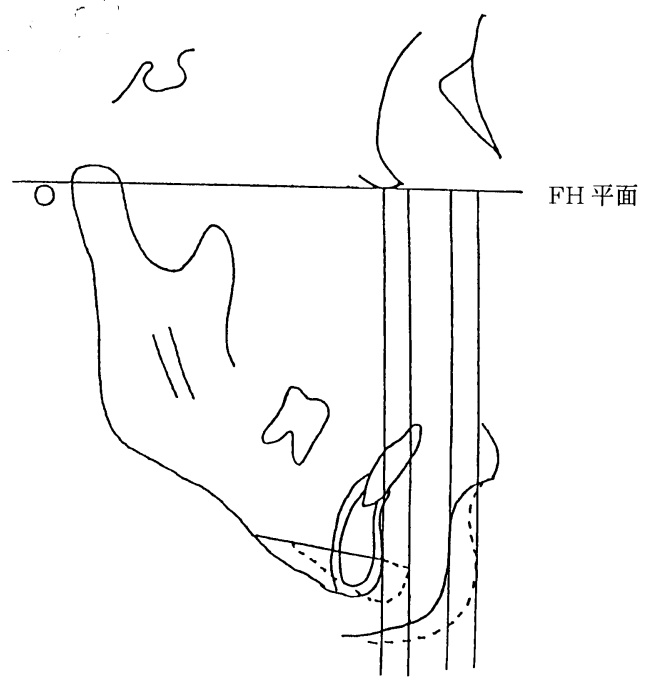

、図1 Pog と Pogs のセファロ上での 水平的位置変化の分析方法

分析に使用した $\mathrm{FH}$ 平面は術後 1 か月のセファロ上の ものを使用した. 実線は術前の下顎骨と，オトガイ部 の硬組織と軟組織の状態を, 点線は術後のオトガイ部 の硬組織と軟組織の状態を示す. 術後 1 か月のセファ ロにそれぞれの時期のセファロの下顎骨部を重ね合わ せ, Pog と Pogs の手術時の移動量, 術後の水平的位 置変化量を計測した。

収, 移動骨片の後方部と下顎骨下縁切断部に骨添加を 認め, 全体的には手術によって生じたステップを丸く 修復するような骨の吸収, 添加形態が認められた。

\section{考察}

軟組織を最大限に付着するオトガイ骨切り前方移動 形成術は, 後戻りや骨吸収の少ない術式として Bell ${ }^{1}$ ) によって紹介された，その背景について Bell ら ${ }^{4)}$ は サルを使った実験において報告しており，軟組織付着 を移動骨片に保存した術式において骨吸収量が少ない のは, 骨膜中を通っている微小血管構造が術後も移動 骨片への血流を維持するため, 骨片の微小な壊死が防 止され，骨切り部において骨片同志の結合，治瘉が速 やかに進行するためであるとしている。また, Polido ら5) は本術式を単独に実施した10症例で, 術後15か月 にわたって骨吸収量を移動骨片の矢状断面積で検討し た結果, 術後 15 か月経過時において術直後と比較し, 側方頭部 X 線規格写真上で平均 $24 \%$ の骨吸収面積を 認めたが, 骨片を固定しているプレートやスクリュー の位置に変化がないことから, 移動骨片の後戻りはな かったとしている.

本研究においてはほとんどの症例において硬組織才 トガイ点の後戻りは認めなかった。 その背景として,
われわれの症例はほとんど下顎骨の後方移動を伴うも のであり，オトガイ部移動骨片が舌骨上筋群によって後 方へ毫引される影響は少ないと考えられる。また，硬組 織オトガイ点の水平的位置変化を認めた症例では, スク リューの位置が変化していないことから移動骨片自体の 後戻りはないが, 移動骨片の上前方で骨吸収が生じたた め硬組織オトガイ点の後退が発生したものと考えられた。

また軟組織オトガイ点においては, 術後 1 か月から 術後 6 力月の間に平均 $-0.6 \mathrm{~mm}$, 術後 6 力月から術後 12 か月の間に平均 $-0.2 \mathrm{~mm}$ の位置変化を認めた。術後 の軟組織形態の変化の原因について, Rubens ら ${ }^{6)}$ は オトガイ筋が骨面から剥離された場合その治癒過程上, 筋組織が微小の萎縮を起こし, 軟組織の厚みや形態に 変化をもたらすとしている. 本術式も軟組織を剥離し てオトガイ部前面の骨面を露出するため, 術後の治癒 過程においてオトガイ部軟組織の萎縮の関与が考えら れた. 同時に手術後のわずかな炎症の残存による軟組 織腫脹の関与も考えるとともに, セファロ撮影時の口 唇の緊張度の差異, 下顎骨, 上顎骨の移動によるオト ガイ部軟組織に加わる筋機能力の変化も軟組織オトガ イ点の位置変化に関与していると考えられた。

このようなことから軟組織を最大限に付着するオト ガイ骨切り前方移動形成術において, 良好な術後安定 性を得るにはオトガイ部軟組織の剥離は必要最小限に とどめ, 移動骨片への血流の維持, 剥離した軟組織の 萎縮の抑制に配慮する必要があると考えられた。

\section{結語}

今回われわれは軟組織を最大限に付着するオトガイ 骨切り前方移動形成術を行った症例を用いて本方法の 術後安定性について若干の考察を加え報告した。

\section{引用 文 献}

1) Bell, W.H.: Surgical correction of dentofacial deformities new concept. Volume 3, W.B. Saunders, Philadelphia, 1985, p57-70.

2）佐藤修一, 川村 仁, 他：広範囲に軟組織を付 着させるオトガイ形成術適用後の術後変化につ いて. 日顎変形誌 8: 19-24 1992.

3）石川晴夫 : オトガイ前方移動形成術の術後変化· 硬組織変化について, 日顎変形誌 2: 164-166 1989.

4) Bell, W.H. Gallagher, D.M., et al: The versatility of genioplasty using a broad pedicle. J Oral Maxillofac Surg 42: 637-645 1984.

5) Polido, W.D., Bell, W.H., et al: Bone resorption, stability and soft tissue changes following large chin advancement J Oral Maxillofac Surg 49: 251-256 1991.

6) Rubens, B.C. and West, R.A.: Potosis of the chin and lip imcompetence: J Oral Maxillofac Surg 47: 359-366 1989. 